\title{
MAXIMIZING THE PRODUCTIVITY AND WATER USE EFFICIENCY OF TOMATO PLANTS (LYCOPERSICON ESCULENTUM MILL.) CULTIVATED IN THE NEW RECLAIMED LANDS USING DIFFERENT IRRIGATION WATER QUANTITIES AND SOME WATER SAVING SUBSTANCES
}

Kamal, A. M.* and M. M. El-Shazly**

* Veget. Res. Dept., Hort. Res. Inst., Agric. Res. Center, Giza, Egypt

**Soil Fertility and Plant Nutrition Dep., Soil, Water and Environment Res. Inst., Agric. Res. Center, Giza, Egypt

\begin{abstract}
Egypt is one of the countries facing great challenges due to its limited water resources, so it has become necessary to study the best ways to rationalize irrigation water use and maximizing the efficient use of water under those circumstances. Two field experiments were conducted at a private farm at Al-Nubaria region, Behira Governorate, Egypt, during the two successive seasons of 2011 and 2012, to investigate the effect of three irrigation water quantities $\left(2400,1800\right.$ and $1200 \mathrm{~m}^{3}$ fed$\left.{ }^{1}\right)$ and some water saving substances, i.e., control, zeolite, super absorbent polymer and K-humate as well as their interactions on growth, chemical composition, yield, water use efficiency and fruit quality of tomato plants (Jacal F1 hybrid) cultivated under drip irrigation system in new reclaimed lands during early summer season.

The obtained results indicate that:

- Increasing water quantity applied to tomato plants up to the highest used level (2400 $\mathrm{m}^{3} \mathrm{fed}^{-1}$ ) significantly increased vegetative growth characters, i.e., stem diameter, foliage fresh weight, leaf area and leaf relative water content as well as total N, P and $\mathrm{K}$ uptake by tomato plants. On the other hand, total chlorophyll contents enhanced significantly with decreasing irrigation water supply. Tomato yield characters, i.e., number of fruits per plant, average fruit weight and total yield increased with increasing irrigation water quantity up to $2400 \mathrm{~m}^{3} \mathrm{fed}^{-1}$. The medium irrigation water level $\left(1800 \mathrm{~m}^{3} \mathrm{fed}^{-1}\right)$ recorded the highest values of water use efficiency. Under the low level of irrigation water $\left(1200 \mathrm{~m}^{3} \mathrm{fed}^{-1}\right)$ tomato fruit quality characters, i.e., flesh firmness, lycopene, TSS and total soluble sugars recorded the highest significant values.

- Soil application of K-humate led to the significant increases in all vegetative growth traits, total NPK uptake, total chlorophyll, yield characters and water use efficiency as well as tomato fruit quality characters compared to soil application of zeolite, super absorbent polymer and control.

- Tomato vegetative growth characters were significantly affected by the combination of $2400 \mathrm{~m}^{3} \mathrm{fed}^{-1}$ and K-humate soil application. Applying 2400 or $1800 \mathrm{~m}^{3} \mathrm{fed}^{-1}$ of irrigation water combined with soil application of K-humate resulted in the highest significant NPK uptake as well as all studied tomato yield characters. Soil application of K-humate combined with the low irrigation level $\left(1200 \mathrm{~m}^{3} \mathrm{fed}^{-1}\right)$ showed the highest significant chlorophyll contents in tomato leaves. Water use efficiency showed the highest value using the medium level of irrigation water (1800 $\mathrm{m}^{3} \mathrm{fed}^{-1}$ ) combined with the soil application of K-humate as compared to the other treatments. Soil application of K-humate combined with the medium irrigation water level $\left(1800 \mathrm{~m}^{3} \mathrm{fed}^{-1}\right)$ or the low level $\left(1200 \mathrm{~m}^{3} \mathrm{fed}^{-1}\right)$ recorded the highest values of tomato fruit quality characters. Using the medium irrigation level $\left(1800 \mathrm{~m}^{3} \mathrm{fed}^{-1}\right)$
\end{abstract}


combined with the soil application of K-humate obtained the highest net return and returned the highest benefit-cost ratio (3.48) in comparison with other treatments.

It could be concluded that irrigation tomato plants with $1800 \mathrm{~m}^{3} \mathrm{fed}^{-1}$ combined with soil application of K-humate $\left(2 \mathrm{~kg} \mathrm{fed}^{-1}\right.$ in every addition, 4 times during the season) incorporated with drip irrigation system could be recommended to improve yield and quality of tomato plants as well as maximizing the water use efficiency by tomato plants, saving about $25 \%$ of the total used irrigation water quantity commonly used in tomato production. Such treatment is found to be economically and more agronomically feasible and can be recommended under drip irrigation system in sandy soil in new reclaimed lands, giving the highest net return and benefit-cost ratio to the farmers.

\section{INTRODUCTION}

Egypt is one of the countries facing serious shortage of water resources, so it is advised to evaluate new possible approaches to minimize the plant water consumption and hence to rationalize irrigation water use. Tomato (Lycopersicon esculentum Mill.) is one of the most important vegetables grown in Egypt in terms of planted area and crop value. Tomato plants are sensitive to water stress and their yield showed high correlation with the amount of irrigation water (Berihun, 2011), therefore, the management of water is critical for both economic yield and fruit quality. That is why many investigations tried to optimize the irrigation regime for tomato; however, most of them reported that the higher growth and yield aspects were associated with higher irrigation treatment (Adams, 1990; Fattahallah, 1992; Condido et al., 2000 and Zhai et al., 2010).

Sandy soils are poor with respect to their physico-biochemical properties (El- Hady and El-Dewiny, 2006) that, unfortunately, resulted in a significant loss of irrigation water through drainage. Minimizing such losses can be applied using soil conditioners, which reported to improve the soil physical condition and increase water irrigation efficiency as well as rationalization of irrigation water (El-Hady et al., 2000; Bernardi et al., 2009 and Ezzat et al., 2011). One of the newest soil conditioners used in this respect is zeolite mineral; it is a hydrated Aluminosilicates, characterized by the ease of retaining and releasing water and exchanging cations without structural changes (Polat et al., 2004). Zeolite application is a soil conditioner, reported to increase soil water-holding capacity, reducing water evaporation, encouraging salt leaching and improving water used efficiently as well as enhancing nutrient use efficiency by increasing $\mathrm{P}$ availability, improving the use of $\mathrm{NH}^{4+}$ and $\mathrm{NO}^{3-}$, reducing leaching losses of exchangeable cations, especially $\mathrm{K}^{+}$, furthermore, acting as slow-release fertilizer (Bernardi et al., 2009). Armandpisheh et al. (2009) reported that zeolite can preserve the moisture of the soil for long-term and can modify the effects of drought stress of plant. Zeolite had positive effects on many plants, including tomato (Valente et al., 1986) and lettuce (Gul et al., 2005). Azarpour et al. (2011) showed that application of $5 \mathrm{t} / \mathrm{ha}$ of zeolite recorded the highest seed yield of cowpea. Additionally, Ashraf (2011) indicate that addition of zeolite in tomato field improved soil bulk density, porosity and increased plant fresh weight, nutrient elements of leaves, number of fruits and total fruits yield. 
Considerable attention has been focused in the last few decades to the use of synthesized conditioners to avail suitable environment for cultivation sandy soils. Among these conditioners are the water absorbent polymers or hydrogels. The use of absorbent polymers had many advantages, it improved the chemical and biological properties of sandy soil by enhancing soil structure, increasing water-holding capacity, improving availability of water to plants and increasing soil aeration as well as reducing soil compaction, leading to better root development (El-Hady et al., 2000). Absorbent polymers was reported to improve the establishment and growth of tomato plants in the deficit of water (Johnson and Piper, 1997). Soil addition of $24 \mathrm{~kg}_{\text {hydrogels }} \mathrm{fed}^{-1}$ increased growth, nutrients uptake and yield as well as water and fertilizers use efficiency by tomato plants in sandy soil (El-Hady and El-Dewiny, 2006). Furthermore, Ezzat et al. (2011) indicated that applying veterra hydrogel at $37.3 \mathrm{~kg} \mathrm{fed}^{-1}$ as a soil conditioner under low water irrigation positively affected vegetative growth characters of potato plants; it enhanced macro, micro-nutrients uptake, plant water relations, total chlorophyll and increased nitrogen use efficiency as well as tuber yields and quality.

Application of humate substances in agriculture as a soil conditioner has been extensively discussed by many researches; they demonstrated conclusively that humic acid showed significant impacts on the soil structure and plant growth (Fong et al., 2007). It was reported that when humic acid applied to tomato plants cultivated in sandy soils, it adds essential organic material necessary for water retention and enhancing the sandy soil's ability to retain and not leach out vital plant nutrients, and hence improving plant growth parameters (Adani et al., 1998). Moreover, humic acid reduces soil compaction and increases the soil fertility aggregation, it enhances the soil exchange capacity, the nutrients and water retention and improves fertilizer efficiency due to its chelating property, in addition, humic acid stimulate the absorption of nutrients and encourage the solubility of many nutrients, i.e., $\mathrm{P}$, $\mathrm{Zn}, \mathrm{Fe}, \mathrm{Mn}$ and $\mathrm{Cu}$ (Hernandez et al., 2001; Nardi et al., 2002; Mikkelsen, 2005 and Selim et al., 2010).

The present study was planned to evaluate the effect of three irrigation water quantities (2400, 1800 and $\left.1200 \mathrm{~m}^{3} \mathrm{fed}^{-1}\right)$ and some water saving substances, i.e., control, zeolite, super absorbent polymer and Khumate as well as their interactions on growth, chemical composition, yield, fruit quality and water use efficiency of tomato plants cultivated under drip irrigation system in new reclaimed lands.

\section{MATERIALS AND METHODS}

Two field experiments were conducted at a private farm at Al-Nubaria region, Behira Governorate, Egypt, during the two successive seasons of 2011 and 2012, to study the effect of three irrigation water quantities (2400, 1800 and $1200 \mathrm{~m}^{3} \mathrm{fed}^{-1}$ ) and some water saving substances, i.e., control, zeolite, super absorbent polymer and K-humate as well as their interactions on growth, chemical composition, yield, fruit quality and water use efficiency of tomato plants cultivated under drip irrigation system in new reclaimed 
lands during early summer season. Table 1 shows some physical and chemical properties of the experiment soil before planting, according to the methods described by Page (1982).

Table 1: Physical and chemical properties of the experimental soil.

\begin{tabular}{|c|c|c|c|c|c|}
\hline \multirow[b]{2}{*}{$\begin{array}{l}\text { Physical } \\
\text { properties }\end{array}$} & \multicolumn{2}{|c|}{ Value } & \multirow[b]{2}{*}{ Chemical Properties } & \multicolumn{2}{|c|}{ Value } \\
\hline & $\begin{array}{c}1^{\text {st }} \\
\text { Season }\end{array}$ & $\begin{array}{c}2^{\text {nd }} \\
\text { Season }\end{array}$ & & $\begin{array}{c}1^{\text {st }} \\
\text { season }\end{array}$ & $\begin{array}{c}2^{\text {nd }} \\
\text { season }\end{array}$ \\
\hline Sand (\%) & 86.0 & 87.2 & Wilting point (\%) & 2.57 & 1.91 \\
\hline Silt (\%) & 9.2 & 7.8 & Water holding capacity (\%) & 25.08 & 26.4 \\
\hline Clay (\%) & 4.8 & 5.0 & Field capacity (\%) & 10.87 & 9.20 \\
\hline Texture class & Sandy & Sandy & \multicolumn{3}{|c|}{ Available nutrients $\left(\mathrm{mg} \mathrm{kg}^{-1}\right)$} \\
\hline $\mathrm{CaCO}_{3}(\%)$ & 5.20 & 4.74 & Nitrogen & 24.7 & 44.3 \\
\hline $\mathrm{pH}$ & 8.42 & 8.38 & Phosphorus & 4.7 & 8.9 \\
\hline $\mathrm{EC} \mathrm{dSm}^{-1}$ & 0.57 & 0.70 & Potassium & 110 & 99.8 \\
\hline
\end{tabular}

On February, $1^{\text {st }}$ week of both seasons, 40 day old tomato seedlings (Jacal F1 hybrid, product of ELITE, USA), were transplanted in open field at $50 \mathrm{~cm}$ apart on one side of the ridge.

\section{Layout of the experiment and treatments:}

The experiment was adopted in a split plot design with three replicates, containing 12 treatments, which were the combination between three water irrigation quantities, i.e., 2400,1800 and $1200 \mathrm{~m}^{3} \mathrm{fed}^{-1}$ as well as some water saving substances, i.e., control, zeolite, super absorbent polymer and K-humate soil applications. The first irrigation quantity is the traditional irrigation water amount added by the farmers in the area. Water irrigation quantities were distributed in the main plots, whereas the used water saving substances were arranged in the sub plots. The plot unit consisted of four ridges each of $1 \mathrm{~m}$ wide and $5 \mathrm{~m}$ long with an area of $20 \mathrm{~m}^{2}$. A distance of 2 $\mathrm{m}$ between plots was left to avoid the infiltration of irrigation water.

During both seasons drip irrigation system was applied using groundwater with $\mathrm{EC}$ of $0.63 \mathrm{dSm}^{-1}$. The drippers used were of a standard 4 $\mathrm{L} \mathrm{h}^{-1}$ discharge at 1.5 bar working pressure. The irrigation treatments started after 20 days from transplanting. The amount of irrigation water at different treatments were adjusted using a water counter and were added according to growth stage of tomato plants during growth season.

Agricultural grade zeolite powder, produced by Shijiazhuang Oushun Minerals Co., Ltd., China, was used, contains $\mathrm{SiO}_{2}(66.45 \%), \mathrm{Al}_{2} \mathrm{O}_{3}(12.3 \%)$, $\mathrm{Fe}_{2} \mathrm{O}_{3}(1.49 \%), \mathrm{K}_{2} \mathrm{O}(1.54 \%), \mathrm{CaO}(3.97 \%)$ and $\mathrm{MgO}(0.92 \%)$, was used at 2 ton fed ${ }^{-1}$. Super absorbent polymer, product of Zhenjiang Agreen Co., Ltd., china, was applied at $40 \mathrm{Kg} \mathrm{fed}^{-1}$. Zeolite and super absorbent polymer were added before transplanting in ditches $(15 \mathrm{~cm}$ depth) next to drippers and then the ditches filled with a wet soil. Potassium humate, manufactured by Zhangjiagang Kangyuan Co., Ltd., China in a powder form, contains $80 \%$ humic acid and $12 \% \mathrm{~K}_{2} \mathrm{O}$ in dry basis, was incorporated with drip irrigation system at $2 \mathrm{~kg} \mathrm{fed}^{-1}$ in every addition. K-humate was applied through four additions, starting 20 days after transplanting and repeated 20 days intervals during the growth seasons. 
The other agricultural treatments for growing tomato plants were followed according to the instruction laid down by Horticulture Research Institute, Agricultural Research Center, Egypt.

\section{Data recorded:}

\section{Growth measurements:}

At 90 days after tomato transplanting, five plants from each plot were randomly taken for determination of stem diameter, foliage fresh weight and leaf area of tomato plants. Leaf area was calculated as a relation between area unit and dry weight of plant leaves as described by Koller (1972). Leaf relative water content (LRWC) was determined in the fully expanded topmost leaf of the main shoot according to the methods of Turner (1981) by recording the fresh weight of the sample leaves and then the leaves were immersed in distilled water. After 2 hours, the leaves were removed, the surface water was blotted-off and the turgid weight recorded. Samples were dried in an oven at $70{ }^{\circ} \mathrm{C}$ to constant weight. Leaf relative water content was calculated using the following formula:

LRWC $(\%)=[(F W-D W) /(T W-D W)] \times 100$

Where; FW: Fresh weight; DW: Dry weight; TW: Turgid weight.

\section{Chemical analysis:}

Representative samples of tomato plant foliage from each plot at the same time were used to determine N, P and K contents then their uptake was calculated considering their concentration as percentage in dry weight basis. Total nitrogen was determined according to the method described by Bremner and Mulvaney (1982). Phosphorus was estimated colormetrically according to Olsen and Sommers (1982) and potassium was determined by flame photometrically as described by Jackson (1973). Representative samples from the fourth upper leaves were taken to determinate total chlorophyll content (SPAD units) using a portable leaf chlorophyll meter (Minolta Model SPAD 501) according to Murquard and Timpton (1987).

\section{Yield and quality measurements:}

All harvested total fruits from each plot at marketable ripe stage along the season were used to determine number of fruits per plant, average fruit weight and total yield as tons per feddan. Water use efficiency (WUE) was calculated according to equation of Begg and Turner (1976) as follows:

WUE $=$ yield $\left(\mathrm{kg} \mathrm{fed}^{-1}\right) /$ water quantity $\left(\mathrm{m}^{3} \mathrm{fed}^{-1}\right)$.

A representative sample of 10 tomato fruits from each experimental plot at the marketable ripe stage was taken from the third harvest for determination some fruits quality characteristics. Flesh firmness $\left(\mathrm{Kg} / \mathrm{cm}^{2}\right)$ was measured by the Magness and Taylor firmness tester, equipped with an 8-mm diameter plunger tip. Two readings were taken from opposite sides of each tomato fruit after the peel was removed. Lycopene was determinate as described by Fish et al. (2002), total soluble solids (TSS) and total soluble sugars contents according to the methods described by AOAC (1990) on the basis of fresh weight.

Statistical analysis:

The obtained data were subjected to statistical analysis as technique of split plot design according Senedcor and Cochran (1980). The treatment 
means were compared using new least significant difference at $5 \%$ level of probability as mentioned by Waller and Duncan (1980).

Economic feasibility of tomato production, i.e., gross return, treatment cost, total variable cost, net return and benefit-cost ratio were calculated based on market prices as average of the two seasons. The benefit-cost ratio was determined according to Boardman et al (2001) by dividing the gross return $\left(\mathrm{LE} \mathrm{fed}^{-1}\right)$ on total variable cost $\left(\mathrm{LE} \mathrm{fed}^{-1}\right)$.

\section{RESULTS AND DISCUSSION \\ Vegetative growth characteristics: \\ Data in Table 2 demonstrate that the different used irrigation} quantities significantly influenced tomato plants vegetative growth characteristics. It is obvious clear that increasing water quantity applied to tomato plants up to the highest used level $\left(2400 \mathrm{~m}^{3} \mathrm{fed}^{-1}\right)$ significantly increased stem diameter, foliage fresh weight and leaf area as well as leaf relative water content of tomato plants in both seasons. The results are in agreement with those reported by Zhai et al. (2010) who found that increasing water level increased plant growth characters of tomato plants.

The improvement of vegetative growth with increasing irrigation level may be due to the proper balance of moisture in plant, which creates favorable conditions for nutrients uptake, photosynthesis and metabolites translocation, which ultimately accelerated the rate of vegetative growth (Ezzo et al., 2010). Moreover the reducing effect of the lowest level of irrigation water $\left(1200 \mathrm{~m}^{3} \mathrm{fed}^{-1}\right)$ may be related to the negative effects of water defect stress on the activities of many enzymes leading to decrease in plant growth and dry matter accumulation (Hamlyn, 1986).

With respect to the effect of the used water saving substances on vegetative growth characteristics of tomato plants, the results showed that the used water saving substances significantly affected stem diameter, foliage fresh weight, leaf area, and leaf relative water content. The highest values were obtained from the addition of K-humate compared to the other treatments and control in both seasons. Such results are coincided with Osman and Abdel All (2008) they found that application of humic acids through drip irrigation system stimulated tomato plants height, number of leaves, stem diameter, number of branches, leaf area and dry weight.

The positive significant effect of the soil application of K-humate on the vegetative growth characters and leaf relative water content of tomato plants could be due to many interpretations. Humic acid (the main component of K-humate) stimulate plant growth by the assimilation of major and minor elements, enzyme activation and/or inhibition, changes in membrane permeability, protein synthesis and finally the activation of biomass production (Meshref et al., 2010). Furthermore, there are various lines of evidence confirming that humic acid is endowed with auxin-like activity, which influences root architecture and metabolism (Nardi et al., 2002). As auxin is a water stress hormone, it is a very effective in causing stomatal closure and its accumulation in stressed leaves plays an important role in the reduction of water loss by transpiration under water stress conditions (Taiz and Zeiger, 
2002). In addition, it is possible that part of the observed bioactivity of humic substances under water stress conditions is the promoting effect on root growth (Nardi et al., 2002). Furthermore, K-humate as a soil application provide a supplemental source of potassium as it contains $12 \% \mathrm{~K}_{2} \mathrm{O}$ in dry basis. Since potassium has substantial effect on enzyme activation, protein synthesis, photosynthesis, stomatal movement and water-relation (turgor regulation and osmotic adjustment) in plants (Marschner, 1995). It was reported that increasing application of $\mathrm{K}^{+}$enhanced photosynthetic rate, plant growth and yield as well as drought resistance under water stress conditions (Egilla et al., 2001). Also, $\mathrm{K}^{+}$deficient negatively affect stomata function and dramatically increase the loss of water from plant (Gething, 1990).

Table 2: Effect of irrigation water quantities and water saving substances as well as their interactions on vegetative growth characteristics of tomato plants during 2011 and 2012 seasons

\begin{tabular}{|c|c|c|c|c|c|c|c|c|}
\hline \multirow{2}{*}{ Treatment } & \multicolumn{2}{|c|}{$\begin{array}{l}\text { Stem diameter } \\
(\mathbf{c m})\end{array}$} & \multicolumn{2}{|c|}{$\begin{array}{l}\text { Foliage fresh } \\
\text { weight (g) }\end{array}$} & \multicolumn{2}{|c|}{$\begin{array}{l}\text { Leaf area } \\
\left(\mathrm{cm}^{2}\right)\end{array}$} & \multicolumn{2}{|c|}{$\begin{array}{c}\text { Leaf relative } \\
\text { water content (\%) }\end{array}$} \\
\hline & $\begin{array}{c}1^{\text {st }} \\
\text { Season }\end{array}$ & $\begin{array}{c}2^{\text {nd }} \\
\text { Season }\end{array}$ & $\begin{array}{c}1^{\text {st }} \\
\text { Season }\end{array}$ & $\begin{array}{c}2^{\text {nd }} \\
\text { Season }\end{array}$ & $\begin{array}{c}1^{\text {st }} \\
\text { Season }\end{array}$ & $\begin{array}{c}2^{\text {nd }} \\
\text { Season }\end{array}$ & $\begin{array}{c}1^{\text {st }} \\
\text { Season }\end{array}$ & $\begin{array}{c}2^{\text {nd }} \\
\text { Season }\end{array}$ \\
\hline \multicolumn{9}{|c|}{ Irrigation quantities $\left(\mathrm{m}^{3}\right.$ fed $\left.{ }^{-1}\right)$ : } \\
\hline 2400 & 2.47 & 2.51 & 1014 & 936.4 & 1911 & 1768 & 83.99 & 84.81 \\
\hline 1800 & 2.20 & 2.20 & 937.7 & 875.9 & 1780 & 1524 & 82.22 & 83.22 \\
\hline 1200 & 1.87 & 1.84 & 790.5 & 750.2 & 1510 & 1310 & 80.29 & 81.72 \\
\hline New LSD at $5 \%$ & 0.112 & 0.124 & 55.23 & 47.57 & 82.11 & 98.47 & 1.60 & 1.51 \\
\hline \multicolumn{9}{|c|}{ Water saving substances: } \\
\hline Control & 2.05 & 1.97 & 846.2 & 781.0 & 1595 & 1394 & 80.90 & 81.83 \\
\hline Zeolite & 2.12 & 2.05 & 887.7 & 811.3 & 1667 & 1446 & 80.92 & 82.63 \\
\hline $\mathrm{SAP}^{*}$ & 2.18 & 2.27 & 910.2 & 860.1 & 1732 & 1557 & 82.42 & 83.38 \\
\hline K-humate & 2.37 & 2.45 & 1012 & 964.2 & 1942 & 1739 & 83.64 & 84.61 \\
\hline New LSD at $5 \%$ & 0.091 & 0.101 & 51.38 & 42.31 & 75.91 & 83.11 & 1.20 & 1.21 \\
\hline \multicolumn{9}{|c|}{ Irrigation quantities X Water saving substances: } \\
\hline Control & 2.41 & 2.31 & 952.0 & 842.4 & 1754 & 1622 & 83.12 & 83.78 \\
\hline ○ Zeolite & 2.47 & 2.39 & 963.3 & 874.3 & 1797 & 1661 & 83.17 & 84.28 \\
\hline 志AP & 2.42 & 2.45 & 1008 & 939.1 & 1906 & 1759 & 83.66 & 84.78 \\
\hline K-humate & 2.59 & 2.89 & 1133 & 1090 & 2187 & 2032 & 86.01 & 86.39 \\
\hline Control & 2.05 & 1.98 & 850.0 & 777.3 & 1602 & 1387 & 81.25 & 81.85 \\
\hline ○ Zeolite & 2.12 & 2.06 & 918.0 & 847.1 & 1732 & 1446 & 80.28 & 82.79 \\
\hline$\infty$ SAP & 2.20 & 2.30 & 952.0 & 885.8 & 1797 & 1544 & 82.18 & 83.03 \\
\hline K-humate & 2.42 & 2.47 & 1031 & 993.3 & 1992 & 1720 & 85.15 & 85.21 \\
\hline Control & 1.70 & 1.62 & 736.7 & 723.6 & 1429 & 1173 & 78.33 & 79.87 \\
\hline ○ Zeolite & 1.77 & 1.70 & 782.0 & 712.6 & 1472 & 1231 & 79.30 & 80.82 \\
\hline$\stackrel{\text { SAP }}{\simeq}$ & 1.91 & 2.05 & 770.7 & 755.4 & 1494 & 1368 & 81.43 & 82.34 \\
\hline K-humate & 2.11 & 2.02 & 872.7 & 809.2 & 1646 & 1466 & 82.11 & 83.83 \\
\hline New LSD a & 0.110 & 0.157 & 63.71 & 54.84 & 79.23 & 91.49 & 2.31 & 2.06 \\
\hline
\end{tabular}

SAP $^{*}$ = super absorbent polymer

Regarding to the effect of the interaction between water irrigation quantities and the used water saving substances on vegetative growth characteristics of tomato plants, it is obviously clear that stem diameter, foliage fresh weight and leaf area were significantly affected by the combination of $2400 \mathrm{~m}^{3} \mathrm{fed}^{-1}$ and soil application of K-humate. Whereas, the highest significant leaf relative water content was observer with the combination of 2400 or $1800 \mathrm{~m}^{3} \mathrm{fed}^{-1}$ and K-humate soil application. The 
results had the same trend during the two seasons. In this respect, Ezzat et al. (2009) reported that decreasing water irrigation to $1600 \mathrm{~m}^{3} \mathrm{fed}^{-1}$ combined with soil application of humic acid had the most significant effect on potato plants height, dry weight and leaf area per plant.

\section{Chemical composition of tomato foliage:}

Data of the uptake of N, P and $\mathrm{K}$ as well as the total chlorophyll contents of tomato plants are presented in Table 3 . The irrigation quantities significantly influenced such characters, i.e., increasing water quantity up to $2400 \mathrm{~m}^{3} \mathrm{fed}^{-1}$ led to the highest significant increases in total uptake of N, P and $\mathrm{K}$. On the other hand, total chlorophyll contents enhanced significantly with decreasing irrigation water supply to the soil. The low level of irrigation water $\left(1200 \mathrm{~m}^{3} \mathrm{fed}^{-1}\right)$ showed the highest values in this respect compared with the other treatments in both seasons of study. Such results are in line with those of Nahar and Gretzmacher (2002) they showed that uptake of nutrients by tomato plants were significantly reduced by water stress.

Concerning the effect of water saving substances on the chemical composition of tomato foliage, the same data clearly reveal that soil application of K-humate showed the highest significant uptake of $\mathrm{N}, \mathrm{P}$ and $\mathrm{K}$ as well as total chlorophyll compared with soil application of zeolite, super absorbent polymer and control treatment, in both seasons (Table 3). Osman and Abdel All (2008) reported similar observations.

The positive effects of the soil application of K-humate on nutrients uptake and chlorophyll contents may be owing to one or more mechanisms. It was reported that the chelating property of humic substances prevents the losses of nutrients from soil through leaching (Hernandez et al., 2001 and Nardi et al., 2002). Humic substances induce the dynamic of $\mathrm{N}$ and $\mathrm{P}$ in soil, stimulate plant respiration, photosynthesis process and favor the formation of soil aggregates (Hernandez et al., 2001). Soil application of humic acid improves soil chemical, physical, biological properties and soil fertility status as well as enhances the exchange capacity of nutrients and water retention (Selim et al., 2010). Humic substances have been shown to increase root ATPase activity and hence increase ions uptake (Canellas et al., 2009). Humic acid, also, stimulate root growth and proliferation of desirable microorganisms in soil (Mikkelsen, 2005). All these actions improve the absorption of nutrients by plants that, differentially reflected on the macronutrient contents in plant. The proposed mode of action by which humic acid stimulate chlorophyll content is that humic substances enhance the absorption of Fe (Pinton et al., 1999), which helping in the development of chlorophyll leading to enhancements in photosynthetic process (Mikkelsen, 2005). Furthermore, K-humate is a rich source of potassium. Since potassium is directly involved in the nutrients absorption through the process of phloem loading as a counter ion to $\mathrm{H}^{+}$(Komor et al., 1980) and so enhancing the mineral content of tomato plant foliage.

Concerning the effect of interaction between irrigation water quantities and water saving substances on chemical characteristics of tomato plants (Table 3). It is obvious clear that irrigation water at 2400 or $1800 \mathrm{~m}^{3}$ fed $^{-1}$ combined with soil application of K-humate resulted in the highest 
significant $\mathrm{N}, \mathrm{P}$ and $\mathrm{K}$ uptake by tomato pants foliage. However, soil application of K-humate combined with the low irrigation level $\left(1200 \mathrm{~m}^{3} \mathrm{fed}^{-1}\right)$ showed the highest significant chlorophyll contents in tomato leaves, in both seasons of study. These results are in agreement with those reported by Ezzat et al. (2009) on potato plants.

Table 3: Effect of irrigation water quantities and water saving substances as well as their interactions on NPK uptake and total chlorophyll contents of tomato plants during 2011 and 2012 seasons

\begin{tabular}{|c|c|c|c|c|c|c|c|c|}
\hline \multirow[t]{2}{*}{ Treatment } & \multicolumn{2}{|c|}{$\begin{array}{c}\text { N uptake } \\
\text { (mg/dry plant } \\
\text { foliage) }\end{array}$} & \multicolumn{2}{|c|}{$\begin{array}{c}\text { P uptake } \\
\text { (mg/dry plant } \\
\text { foliage) }\end{array}$} & \multicolumn{2}{|c|}{$\begin{array}{c}\text { K uptake } \\
\text { (mg/dry plant } \\
\text { foliage) }\end{array}$} & \multicolumn{2}{|c|}{$\begin{array}{l}\text { Total chlorophyll } \\
\text { (SPAD units) }\end{array}$} \\
\hline & $\begin{array}{c}1^{\text {st }} \\
\text { Season }\end{array}$ & $\begin{array}{l}2^{\text {nd }} \\
\text { Season }\end{array}$ & $\begin{array}{c}1^{\text {st }} \\
\text { Season }\end{array}$ & $\begin{array}{c}2^{\text {nd }} \\
\text { Season }\end{array}$ & $\begin{array}{c}1^{\text {st }} \\
\text { Season }\end{array}$ & $\begin{array}{c}2^{\text {nd }} \\
\text { Season }\end{array}$ & $\begin{array}{c}1^{\text {st }} \\
\text { Season }\end{array}$ & $\begin{array}{c}2^{\text {nd }} \\
\text { Season }\end{array}$ \\
\hline \multicolumn{9}{|c|}{ Irrigation quantities $\left(\mathrm{m}^{3} \mathrm{fed}^{-1}\right)$ : } \\
\hline 2400 & 6256 & 5829 & 455.0 & 418.3 & 4580 & 4374 & 45.37 & 50.18 \\
\hline 1800 & 5903 & 5283 & 415.2 & 388.0 & 4245 & 4029 & 49.17 & 52.84 \\
\hline 1200 & 4687 & 4369 & 352.5 & 326.4 & 3522 & 3404 & 52.70 & 55.61 \\
\hline New LSD at $5 \%$ & 211.3 & 284.3 & 21.54 & 20.48 & 172.6 & 195.2 & 1.94 & 2.07 \\
\hline \multicolumn{9}{|c|}{ Water saving substances: } \\
\hline Control & 5182 & 4856 & 371.3 & 341.8 & 3826 & 3684 & 47.91 & 52.22 \\
\hline Zeolite & 5355 & 4979 & 390.6 & 366.7 & 3945 & 3796 & 48.14 & 52.21 \\
\hline $\mathrm{SAP}^{\star}$ & 5675 & 5237 & 403.6 & 373.7 & 4084 & 3959 & 48.97 & 52.55 \\
\hline K-humate & 6250 & 5567 & 464.5 & 428.0 & 4608 & 4303 & 51.30 & 54.51 \\
\hline New LSD at $5 \%$ & 170.3 & 235.8 & 19.45 & 18.54 & 145.7 & 155.7 & 1.59 & 1.62 \\
\hline \multicolumn{9}{|c|}{ Irrigation quantities X Water saving substances: } \\
\hline Control & 5845 & 5697 & 421.4 & 385.7 & 4380 & 4112 & 44.31 & 49.23 \\
\hline ○ Zeolite & 5988 & 5734 & 429.7 & 404.4 & 4357 & 4199 & 44.00 & 48.88 \\
\hline ¿ & 6252 & 5784 & 454.2 & 413.0 & 4564 & 4495 & 45.31 & 50.56 \\
\hline K-humate & 6940 & 6099 & 514.5 & 472.9 & 5018 & 4689 & 47.84 & 52.04 \\
\hline Control & 5238 & 4852 & 366.3 & 333.1 & 3889 & 3699 & 47.86 & 52.17 \\
\hline ঃ Zeolite & 5572 & 5010 & 401.4 & 367.6 & 4046 & 3826 & 48.44 & 53.02 \\
\hline$\infty \widehat{\mathrm{SAP}}$ & 6054 & 5423 & 405.0 & 392.7 & 4188 & 4088 & 48.83 & 52.03 \\
\hline K-humate & 6748 & 5846 & 487.9 & 451.5 & 4857 & 4504 & 51.53 & 54.14 \\
\hline Control & 4462 & 4020 & 326.1 & 306.7 & 3208 & 3242 & 51.55 & 55.27 \\
\hline ○ Zeolite & 4505 & 4194 & 340.8 & 328.0 & 3432 & 3363 & 51.97 & 54.74 \\
\hline$\simeq$ SAP & 4720 & 4505 & 351.7 & 318.3 & 3499 & 3294 & 52.76 & 55.06 \\
\hline K-humate & 5062 & 4757 & 391.2 & 352.7 & 3949 & 3716 & 54.52 & 57.35 \\
\hline New LS & 200.4 & 261.6 & 28.14 & 23.28 & 194.5 & 210.3 & 1.64 & 1.84 \\
\hline
\end{tabular}

SAP $^{*}=$ super absorbent polymer

Yield characteristics:

Significant differences were detected among the different irrigation quantity treatments regarding yield characteristics and water use efficiency of tomato plants. Data presented in Table 4 show that number of fruits per plant, average fruit weight and total yield (ton fed ${ }^{-1}$ ) increased significantly with increasing irrigation water quantity up to $2400 \mathrm{~m}^{3} \mathrm{fed}^{-1}$. Meanwhile, the medium irrigation water level $\left(1800 \mathrm{~m}^{3} \mathrm{fed}^{-1}\right)$ recorded the highest values of water use efficiency. In this respect, Fattahallah (1992) showed that using water irrigation amount at 6.68 liters $/ \mathrm{m}^{2}$ compared with $1.67,3.34$ and 5.01 Liters $/ \mathrm{m}^{2}$ increased number of tomato fruits per plant, average fruit weight and total yield. In addition, Condido et al. (2000) used three amounts of irrigation water (33, 66 and 100\%) based on the economic requirement of tomato, they found that tomato yield increased with increasing rates of irrigation water, the maximum yield was obtained with $100 \%$ level. Moreover, Berihun (2011) indicated that average weight of tomato fruits, marketable and 
total fruit yield were significantly affected by the amount of water applied. Forasmuch, Zhai et al. (2010) and Berihun (2011) all work on tomato demonstrated that irrigation water use efficiency tended to increase with a decline of irrigation amount.

Such results clearly emphases the importance of increasing soil moisture content in the sandy soil on yield aspects of tomato plants. This could be related to the high water quantity applied to tomato plants led to keep higher water content in the plant tissues (Table 2) and this, differentially, reflected on yield than those under water stress. This also may be back to the better performance of growth characters of tomato plants (Table 2) and enhancing the nutrients status in tomato plants (Table 3 ) which, encourage the plants to utilize nutrients more efficiently; rather increase yield attributes.

With respect to the effect of the used water saving substances on yield characteristics of tomato plants, the same data illustrate that number of fruits per plant, average fruit weight and total yield (ton fed-1) as well as water use efficiency were significantly influenced by the soil application of K-humate followed by the application of super absorbent polymer in comparing with zeolite soil application and control treatment. The results were the same during the two years of the study. In this respect, Osman and Abdel All (2008) on tomato reported that incorporated humic acid with drip irrigation system increased average fruit weight and total yield of tomato.

The positive effect of the soil application of K-humate on yield characteristics and water use efficiency of tomato plants could be related to its enhancing effect on vegetative growth and leaf relative water content of tomato plants (Table 2), in addition, promoting the uptake of $\mathrm{N}, \mathrm{P}$ and $\mathrm{K}$ uptake as well as total chlorophyll (Table 3).

Regarding the interaction between irrigation water quantities and water saving substances on yield and water use efficiency of tomato plants, it is clear that using the high water irrigation level $\left(2400 \mathrm{~m}^{3} \mathrm{fed}^{-1}\right)$ or the medium level $\left(1800 \mathrm{~m}^{3} \mathrm{fed}^{-1}\right)$ combined with the soil application of K-humate resulted in the highest significant number of fruits per plant, average fruit weight and total yield. Meanwhile, water use efficiency showed the highest value using the medium level $\left(1800 \mathrm{~m}^{3} \mathrm{fed}^{-1}\right)$ with soil application of $\mathrm{K}$-humate as compared to the other treatments. The results are in the same line during both seasons.

Such benefits of that combination between the medium level of irrigation water $\left(1800 \mathrm{~m}^{3} \mathrm{fed}^{-1}\right)$ and the soil application of K-humate on yield aspects and water use efficiency of tomato plants may be related to that humic acid application (the main component of K-humate) resulted in increasing endogenous cytokinin and auxin levels which possibly leading to improve plant drought resistance (Zhang and Ervin, 2004). Moreover, Khumate provide an additional source of $\mathrm{K}^{+}$, which is closely related with increasing yield (Egilla et al., 2001). Furthermore, $\mathrm{K}^{+}$is important for the stomata function and reducing water losses from plant (Gething, 1990). Such gains can explain the enhancement of yield and water use efficiency. 
Table 4: Effect of irrigation water quantities and water saving substances as well as their interactions on yield characteristics and water use efficiency of tomato during 2011 and 2012 seasons

\begin{tabular}{|c|c|c|c|c|c|c|c|c|}
\hline \multirow{2}{*}{ Treatment } & \multicolumn{2}{|c|}{ No. fruits/plant } & \multicolumn{2}{|c|}{$\begin{array}{l}\text { Average fruit } \\
\text { weight (g) }\end{array}$} & \multicolumn{2}{|c|}{$\begin{array}{l}\text { Total yield } \\
\left(\text { Ton fed }^{-1}\right)\end{array}$} & \multicolumn{2}{|c|}{$\begin{array}{c}\text { Water use } \\
\text { efficiency }\left(\mathrm{kg} / \mathrm{m}^{3}\right)\end{array}$} \\
\hline & $\begin{array}{c}1^{\text {st }} \\
\text { Season }\end{array}$ & $\begin{array}{c}2^{\text {nd }} \\
\text { Season }\end{array}$ & $\begin{array}{c}1^{\text {st }} \\
\text { Season }\end{array}$ & $\begin{array}{c}2^{\text {nd }} \\
\text { Season }\end{array}$ & $\begin{array}{c}1^{\text {st }} \\
\text { Season }\end{array}$ & $\begin{array}{c}2^{\text {nd }} \\
\text { Season }\end{array}$ & \begin{tabular}{c|}
$1^{\text {st }}$ \\
Season
\end{tabular} & $\begin{array}{c}2^{\text {nd }} \\
\text { Season }\end{array}$ \\
\hline \multicolumn{9}{|c|}{ Irrigation quantities $\left(\mathrm{m}^{3}\right.$ fed $\left.^{-1}\right)$ : } \\
\hline 2400 & 38.20 & 44.18 & 112.2 & 110.1 & 34.30 & 38.91 & 14.29 & 16.21 \\
\hline 1800 & 36.96 & 42.20 & 107.5 & 105.4 & 31.83 & 35.64 & 17.69 & 19.80 \\
\hline 1200 & 31.43 & 36.53 & 80.50 & 78.56 & 20.27 & 22.99 & 16.90 & 19.16 \\
\hline New LSD at 5\% & 1.45 & 1.54 & 3.84 & 4.41 & 1.81 & 1.68 & 0.54 & 0.61 \\
\hline \multicolumn{9}{|c|}{ Water saving substances } \\
\hline Control & 34.19 & 39.65 & 97.45 & 95.07 & 27.06 & 30.51 & 15.21 & 17.22 \\
\hline Zeolite & 34.49 & 40.06 & 98.02 & 96.19 & 27.32 & 31.20 & 15.46 & 17.61 \\
\hline SAP $^{*}$ & 35.79 & 40.65 & 100.3 & 97.45 & 29.08 & 32.12 & 16.41 & 18.07 \\
\hline K-humate & 37.64 & 43.50 & 104.5 & 103.3 & 31.75 & 36.23 & 18.10 & 20.66 \\
\hline New LSD at 5\% & 1.21 & 1.34 & 3.25 & 3.11 & 1.03 & 1.12 & 0.47 & 0.41 \\
\hline \multicolumn{9}{|c|}{ Irrigation quantities X Water saving substances: } \\
\hline Control & 37.01 & 43.40 & 110.1 & 107.2 & 32.59 & 37.22 & 13.58 & 15.51 \\
\hline ○ Zeolite & 37.20 & 43.31 & 111.6 & 109.8 & 33.21 & 38.04 & 13.84 & 15.85 \\
\hline S SAP & 38.92 & 44.35 & 112.8 & 110.0 & 35.12 & 39.03 & 14.63 & 16.26 \\
\hline K-humate & 39.67 & 45.66 & 114.3 & 113.2 & 36.27 & 41.35 & 15.11 & 17.23 \\
\hline Control & 36.43 & 40.09 & 104.4 & 101.9 & 30.43 & 32.68 & 16.91 & 18.16 \\
\hline ○ Zeolite & 34.88 & 41.72 & 104.2 & 100.5 & 29.08 & 33.54 & 16.16 & 18.63 \\
\hline$\stackrel{\infty}{\text { SAP }}$ & 36.98 & 42.19 & 107.9 & 104.8 & 31.92 & 35.37 & 17.73 & 19.65 \\
\hline K-humate & 39.56 & 44.78 & 113.4 & 114.4 & 35.89 & 40.98 & 19.94 & 22.77 \\
\hline \multirow{5}{*}{ 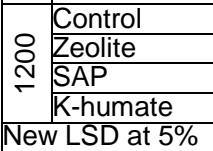 } & 29.14 & 35.47 & 77.86 & 76.11 & 18.15 & 21.60 & 15.13 & 18.01 \\
\hline & 31.40 & 35.16 & 78.27 & 78.28 & 19.66 & 22.02 & 16.38 & 18.35 \\
\hline & 31.48 & 35.41 & 80.17 & 77.55 & 20.19 & 21.97 & 16.83 & 18.31 \\
\hline & 33.68 & 40.06 & 85.70 & 82.28 & 23.09 & 26.37 & 19.24 & 21.98 \\
\hline & 1.28 & 1.25 & 3.37 & 3.49 & 1.05 & 1.32 & 0.59 & 0.30 \\
\hline
\end{tabular}

SAP $^{*}$ = super absorbent polymer

Fruit quality characteristics:

The present data in Table 5 declare the effect of irrigation water quantities on fruit quality characteristics of tomato, it is clear that under insufficient water quantity $\left(1200 \mathrm{~m}^{3} \mathrm{fed}^{-1}\right)$, tomato fruit quality characteristics, i.e., flesh firmness, lycopene, TSS and total soluble sugars recorded the highest significant values. The lowest values in this respect were obtained using the high irrigation water quantity $\left(2400 \mathrm{~m}^{3} \mathrm{fed}^{-1}\right)$, in both seasons. Such results were confirmed by the work of Adams (1990), who found that restricting water to $80 \%$ of water requirement for tomato plants resulted in the best fruit quality in compared with 100 or $120 \%$ levels. Moreover, Fattahallah (1992) stated that vitamin C, TSS and fruit firmness decreased with increasing rates of water. In addition, Shinohara et al. (1995) work on tomato observed that water stress decreased tomato fruit yield and improved tomato fruit quality, it relatively promotes the photosynthetic translocation into fruit and hence improves the fruit quality. In this respect, Condido et al. (2000) mentioned that increasing rates of irrigation water to $100 \%$ from the economic requirement of irrigation water reduced the dry matter content, TSS and firmness. 
The enhancing effect of restricting water irrigation treatment on tomato fruit quality characteristics can be explained because water stress affects carbohydrate metabolism, protein synthesis and the activities of many enzymes that may reflect a change in the balance between rates of synthesis and degradation (Hamlyn, 1986).

Regarding to the effect of the used water saving substances on tomato fruit quality characteristics, the same data clearly reveal that soil application of K-humate resulted in the highest significant values of flesh firmness, lycopene, TSS and total soluble sugars followed by the soil application of super absorbent polymer compared to the other treatments, in the both seasons. Recently, Osman and Abdel All (2008) concluded that the average weight of fruit, fruit firmness, total soluble solids, vitamin C, titratable acidity and total sugars of tomato fruits significantly increased with incorporation of humic acid with drip irrigation system.

The positive effect of K-humate soil application on tomato fruit quality could be explained on the basis that humic acid has been observed to affect the photosynthetic metabolism by decreasing starch content accompanied by an increasing of soluble sugars (Merlo et al., 1991). In addition, K-humate is considered as significant supplement of $\mathrm{K}^{+}$, since potassium plays an important role in water status of plant, promoting the translocation of newly synthesized photosynthetics and mobilization of stored materials as well as promoting the synthesis of sugars and polysaccharides (Mengel and Kirkby, 1982).

As for the effect of the interaction between irrigation water quantities and the used water saving substances on quality characteristics of tomato fruits. It is clear that using $1800 \mathrm{~m}^{3}$ or $1200 \mathrm{~m}^{3} \mathrm{fed}^{-1}$ of irrigation water with the soil application of K-humate resulted in the highest significant flesh firmness, lycopene, TSS and total soluble sugars contents in tomato fruits and this was true in both season of study. Obtained results are in the line with those of Ezzat et al. (2009) on potato.

Economic feasibility:

Economic feasibility of tomato production as affected by the interaction between irrigation water quantities and the used water saving substances are demonstrated in Table 6 . It is clear that the highest net return (26315 LE fed-1) was obtained using the medium irrigation level $\left(1800 \mathrm{~m}^{3} \mathrm{fed}\right.$ $\left.{ }^{1}\right)$ combined with the soil application of K-humate. Such treatment returns the highest benefit-cost ratio (3.48) in comparison with other treatments, thus, this treatment proved to be the most economical strategy for tomato production under the conditions of this study.

Generally, this investigation conclude that irrigation tomato plants with $1800 \mathrm{~m}^{3} \mathrm{fed}^{-1}$ combined with soil application of K-humate incorporated with drip irrigation system could be recommended to improve yield and quality of tomato plants as well as maximizing the water use efficiency, saving about $25 \%$ of the total used irrigation water quantity in tomato production. Such treatment is found to be economically and agronomically feasible and can be recommended under drip irrigation system in sandy soil 
in new reclaimed lands, giving the highest net return and benefit-cost ratio to the farmers.

Table 5: Effect of irrigation water quantities and water saving substances as well as their interactions on fruit quality characteristics of tomato

\begin{tabular}{|c|c|c|c|c|c|c|c|c|}
\hline \multirow[b]{2}{*}{ Treatment } & \multicolumn{2}{|c|}{$\begin{array}{c}\text { Flesh firmness } \\
\left(\mathrm{Kg} / \mathrm{cm}^{2}\right)\end{array}$} & \multicolumn{2}{|c|}{$\begin{array}{c}\text { Lycopene } \\
\text { (mg kg }{ }^{-1} \text { fresh fruit) }\end{array}$} & \multicolumn{2}{|c|}{$\begin{array}{l}\text { Total soluble } \\
\text { solids (\%) }\end{array}$} & \multicolumn{2}{|c|}{$\begin{array}{l}\text { Total soluble } \\
\text { sugars (\%) }\end{array}$} \\
\hline & $\begin{array}{c}1^{\text {st }} \\
\text { Season }\end{array}$ & $\begin{array}{c}2^{\text {nd }} \\
\text { Season }\end{array}$ & $\begin{array}{c}1^{\text {st }} \\
\text { Season }\end{array}$ & $\begin{array}{l}2^{\text {nd }} \\
\text { Season }\end{array}$ & \begin{tabular}{|c|}
$1^{\text {st }}$ \\
Season \\
\end{tabular} & $\begin{array}{c}2^{\text {nd }} \\
\text { Season }\end{array}$ & $\begin{array}{c}1^{\text {st }} \\
\text { Season }\end{array}$ & $\begin{array}{l}2^{\text {nd }} \\
\text { Season }\end{array}$ \\
\hline \multicolumn{9}{|c|}{ Irrigation quantities $\left(\mathrm{m}^{3} \mathrm{fed}^{-1}\right)$ : } \\
\hline 2400 & 1.18 & 1.28 & 55.59 & 52.22 & 5.56 & 6.30 & 2.86 & 3.05 \\
\hline 1800 & 1.29 & 1.42 & 59.29 & 54.24 & 6.35 & 6.97 & 3.07 & 3.21 \\
\hline 1200 & 1.37 & 1.50 & 61.37 & 56.09 & 6.53 & 7.26 & 3.20 & 3.33 \\
\hline New LSD at $5 \%$ & 0.07 & 0.05 & 1.71 & 1.62 & 0.17 & 0.22 & 0.12 & 0.11 \\
\hline \multicolumn{9}{|c|}{ Water saving substances: } \\
\hline Control & 1.25 & 1.33 & 58.25 & 52.83 & 5.99 & 6.62 & 3.00 & 3.08 \\
\hline Zeolite & 1.25 & 1.37 & 58.10 & 52.82 & 6.08 & 6.77 & 3.00 & 3.12 \\
\hline $\mathrm{SAP}^{*}$ & 1.28 & 1.40 & 58.38 & 54.24 & 6.13 & 6.84 & 3.01 & 3.19 \\
\hline K-humate & 1.35 & 1.49 & 60.26 & 56.83 & 6.40 & 7.13 & 3.17 & 3.39 \\
\hline New LSD at $5 \%$ & 0.05 & 0.04 & 1.54 & 1.46 & 0.18 & 0.20 & 0.09 & 0.08 \\
\hline \multicolumn{9}{|c|}{ Irrigation quantities X Water saving substances: } \\
\hline Control & 1.15 & 1.21 & 55.14 & 51.74 & 5.34 & 6.11 & 2.81 & 2.94 \\
\hline ○ Zeolite & 1.14 & 1.23 & 54.05 & 50.38 & 5.48 & 6.34 & 2.83 & 3.01 \\
\hline S SAP & 1.19 & 1.27 & 55.87 & 52.17 & 5.52 & 6.22 & 2.80 & 3.04 \\
\hline K-humate & 1.25 & 1.39 & 57.29 & 54.57 & 5.91 & 6.52 & 2.99 & 3.22 \\
\hline Control & 1.24 & 1.35 & 58.06 & 51.77 & 6.28 & 6.61 & 3.02 & 3.10 \\
\hline ○ Zeolite & 1.26 & 1.40 & 59.08 & 52.65 & 6.25 & 6.83 & 2.98 & 3.13 \\
\hline$\infty$ SAP & 1.29 & 1.42 & 58.88 & 54.72 & 6.30 & 7.05 & 3.06 & 3.17 \\
\hline K-humate & 1.36 & 1.51 & 61.12 & 57.80 & 6.58 & 7.37 & 3.22 & 3.44 \\
\hline Control & 1.35 & 1.44 & 61.55 & 54.97 & 6.34 & 7.13 & 3.16 & 3.20 \\
\hline ○ Zeolite & 1.34 & 1.48 & 61.17 & 55.42 & 6.51 & 7.15 & 3.19 & 3.22 \\
\hline$\simeq$ SAP & 1.36 & 1.51 & 60.39 & 55.84 & 6.56 & 7.26 & 3.17 & 3.37 \\
\hline K-humate & 1.43 & 1.56 & 62.36 & 58.11 & 6.72 & 7.51 & 3.29 & 3.51 \\
\hline New LSD at $5 \%$ & 0.06 & 0.07 & 1.67 & 1.54 & 0.24 & 0.22 & 0.10 & 0.09 \\
\hline
\end{tabular}

SAP $^{\star}=$ super absorbent polymer

Table 6: Economic feasibility of tomato production as affected by the interaction between irrigation water quantities and water saving substances during 2011 and 2012 seasons

\begin{tabular}{|c|c|c|c|c|c|c|c|}
\hline Treatment & $\begin{array}{l}\text { Total yield } \\
\left({\left.\text { Ton } \text { fed }^{-1}\right)^{(1)}}^{(1)}\right.\end{array}$ & $\begin{array}{c}\text { Gross } \\
\text { return } \\
\left(\text { LE fed }^{-1}\right)^{(2)}\end{array}$ & $\begin{array}{c}\text { Treatment } \\
\text { cost } \\
\left(\text { LE fed }^{-1}\right)^{(3)}\end{array}$ & 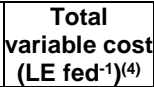 & $\mid \begin{array}{l}\text { Net return } \\
\left(\text { LE fed }^{-1}\right)^{(5)}\end{array}$ & $\begin{array}{c}\text { Benefit } \\
\text { cost ratio(6) }\end{array}$ & Order \\
\hline Control & 34.91 & 38401 & 1650 & 12220 & 26181 & 3.14 & 3 \\
\hline ○ Zeolite & 35.63 & 39193 & 4750 & 15320 & 23873 & 2.56 & 7 \\
\hline$\stackrel{\sim}{\sim} \mathrm{SAP}^{\star}$ & 37.08 & 40788 & 3750 & 14320 & 26468 & 2.85 & 5 \\
\hline K-humate & 38.81 & 42691 & 1990 & 12560 & 30131 & 3.40 & 2 \\
\hline Control & 31.56 & 34716 & 1250 & 11820 & 22896 & 2.94 & 4 \\
\hline ৪ Zeolite & 31.31 & 34441 & 4350 & 14920 & 19521 & 2.31 & 9 \\
\hline$\infty$ SAP & 33.65 & 37015 & 3350 & 13920 & 23095 & 2.66 & 6 \\
\hline K-humate & 38.44 & 42284 & 1590 & 12160 & 30124 & 3.48 & 1 \\
\hline Control & 19.88 & 21868 & 825 & 11395 & 10473 & 1.92 & 10 \\
\hline ৪ Zeolite & 20.84 & 22924 & 3925 & 14495 & 8429 & 1.58 & 12 \\
\hline$\stackrel{\leftarrow}{\sim}$ SAP & 21.08 & 23188 & 2925 & 13495 & 9693 & 1.72 & 11 \\
\hline K-humate & 24.73 & 27203 & 1165 & 11735 & 15468 & 2.32 & 8 \\
\hline
\end{tabular}

SAP $^{*}$ = super absorbent polymer

(1) Tomato total yield as average of the two seasons. (2) Gross return as total yield (ton fed 1) $x 900$ LE Ton $^{-1}$. (3) Treatment cost was calculated according to the following prices: Zeolite $=1500 \mathrm{LE} / \mathrm{ton}$, Super absorbent polymer $=50 \mathrm{LE} / \mathrm{Kg}$, K-humate = $30 \mathrm{LE} / \mathrm{Kg}$. (4) Total variable cost $\left(\right.$ LE fed $\left.^{-1}\right)$ include: Treatment cost plus land leasehold, transplants, $N, P$ and $K$ fertilizers, microelements, pesticides, labors, and other cultural practices which equal nearly $10570 \mathrm{LE} \mathrm{fed}^{-1}$. (5) = (2)-(4). (6)= (2)/(4). 


\section{REFERENCES}

Adams, S. P. (1990). Effect of watering on the yield, quality and composition of tomato grown in legs of peat. J. Horti. Sci., 65(6): 667-674.Adani, F.; P. Genevini; P. Zaccheo and G. Zocchi (1998). The effect of commercial humic acid on tomato plant growth and mineral nutrition. J. Plant Nutr., 21: 561-575.

AOAC (1990). Official Methods of Analysis of the Association of Official Edition, Washington, D. C.

Armandpisheh, O.; H. Irannejad; I. Allahdadi; R. Amiri; A. Ghaffar Ebadi and A. A. Koliaei (2009). Application of zeolite in drought stress on Vigority of canola Seed (Zarfam Cultivar). American-Eurasian J. Agric. and Environ. Sci., 5 (6): 832-837.

Ashraf, S. (2011). The effect of different substrates on the vegetative, productivity characters and relative absorption of some nutrient elements by the tomato plant. Advances in Environmental Biol., 5(10): 3091-3096.

Azarpour, E.; M. K. Motamed; M. Moraditochaee and H. R. Bozorgi (2011). Effects of zeolite application and nitrogen fertilization on yield components of cowpea (Vigna unguiculata L.). World Applied Sci., J., 14 (5): 687-692.

Begg, J. E., and N. C. Turner (1976). Crop water deficits. Advances in Agron., 28, pp.189.

Berihun, B. (2011). Effect of mulching and amount of water on the yield of tomato under drip irrigation. J. Hort. and Forestry, 3(7):200-206.

Bernardi, A. C. C.; F. C. Mendonca; C. G. Werneck; P. G. Haim and M. B. M. Monte (2009). Water availability and rice yield due to levels of zeolitic concentrate. Irriga, 14:123-134.

Boardman, A. E.; D. H. Greenberg; A. R. Vining and D. L. Weimer (2001). Cost-benefit analysis. Concepts and practice. $2^{\text {nd }}$ ed. Prentice Hall, Upper Saddle River.

Bremner, J. M. and C. S. Mulvaney (1982). Total nitrogen. In: Page, A. L., R. H. Miller and D. R. Keeney (eds.) Methods of Soil Analysis. Part 2, Amer. Soc. Agron. Madison, W. I. USA, 595- 624.

Canellas, L. P.; R. Spaccini; A. Piccolo; L. B Dobbss; A. L. OkorokovaFacanha, and G. D. Santos, (2009). Relationships between chemical characteristics and root growth promotion of humic acids isolated from Brazilian oxisols. Soil Sci., 174:611-620.

Condido, V. M.; M. Pemiola and A.R. Rivelli (2000). Water use efficiency and yield response of long time storage tomato. Acta Hort., 537:789-797.

Egilla, J.N.; Davies, F.T. Jr. and Drew, M.C. 2001. Effect of potassium on drought resistance of Hibiscus rosa-sinensis cv. Leprechaun: Plant growth, leaf macro and micronutrient content and root longevity. Plant and Soil 229(2): 213-224.

El-Hady, O. A. and C. Y. El-Dewiny (2006). The conditioning effect of composts (natural) or/and acrylamide hydrogels (synthesized) on a sandy calcareous soil 1 . Growth response, nutrients uptake and water 
and fertilizers use efficiency by tomato plants. J. Appl. Sci. Res., 2(11):890-898.

El-Hady, O. A.; S. A. Abou-Sedera and A. A. Abd El-Kader (2000). Hydrogels for improving the conditioning effect of manures II-Influence on some chemical and biological properties of sandy soil. Egypt. Soil Sci. Soc.; Golden Jubilee Cong. On "Soil and sustainable agriculture in the new century" Oct. 23-25, Cairo Egypt.

Ezzat, A. S.; A. A. El-Awady and H. M. I. Ahmed (2011). Improving nitrogen utilization efficiency by potato (Solanum tuberosum L.) B. Effect of irrigation intervals, nitrogen rates and veterra hydrogel on growth, yield, quality and nutrient uptake. Nature and Sci., 9(7):34-41.

Ezzat, A. S.; U. M. Saif El-deen and A. M. Abd El-Hameed (2009). Effect of irrigation water quantity, antitranspirant and humic acid on growth, yield, nutrients content and water use efficiency of potato (Solanum tuberosum L.). J. Agric. Sci., Mansoura Univ., 34(12):11585-11603.

Ezzo, M.I.; A. A. Glala; A. M. H. Habib and A. A. Helaly (2010). Response of sweet pepper grown in sandy and clay soil lysimeters to water regimes. American-Eurasian J. Agric. and Environ. Sci., 8 (1):18-26.

Fattahallah, M. A. (1992). Response of tomato to various irrigation regimes in relation to farmyard manure fertilization: 2 , yield and fruit quality. Menofiya J. Agric. Res., 17(3):1327-1351.

Fish, W. W.; P. Perkins-Veaziea and J. K. Collins (2002). Quantitative assay for lycopene that utilizes reduced volumes of organic solvents. J. Food Comp. Anal., 15(3):309-317.

Fong, S. S.; L. Seng and H. B. Mat (2007). Reuse of Nitric acid in the oxidative pretreatment step for preparation of humic acids from low rank coal of Mukah. Sarawak. J. Braz. Chem. Soc., 18(1): 41-46.

Gething, P. A. (1990). Potassium and water relationships. In: Potash facts. IPI. Bern.

Gul, A.; D. Erogul and A. R. Ongun (2005). Comparison of the use of zeolite and perlite as substrate for crisp-head lettuce. Sci. Hortic., 106:464471.

Hamlyn, G. J. (1986). Drought and drought tolerance in plants and microclimate. Cambridge Univ. Press, Cambridge, London, New York, New Rochelle, Melbourne, Sydney, pp. 212-237.

Hernandez, T.; C. Garcia; J. A. Pascual and J. L. Moreno (2001). Humic acids from various organic wastes and more traditional organic matter: Effect on plant growth and nutrient absorption. Understanding and managing organic matter in soils, sediments and waters. Proceeding of the $9^{\text {th }}$ international conference of the international humic substances. Society University of Adelaide, Adelaide, Australia, 21 $21^{\text {st }}-25^{\text {th }}$ September. Editors R. S. Swift and K. M. Spark.

Marschner, H. (1995). Mineral Nutrition of Higher Plants. $2^{\text {nd }}$ ed. Academic Press, San Diego, California, USA.

Mengel, K. and E. A. Kirkby (1982). Textbook of principles of plant nutrition. $3^{\text {rd }}$ ed. P. 655. International Potash Institute, Bern, Switzerland.

Jackson, M. L. (1973). Soil chemical analysis. Prentic-Hall, India, 144-197. 
Johnson, M. S. and C. D. Piper (1997). Cross-linked, water-storing polymers as aids to drought tolerance of tomatoes in growing media. J. Agronomy and Crop Sci., 178:23-27.

Koller, H. R. (1972). Leaf area-leaf weight relationship in soybean canopy. Crop. Sci., 12:180-183.

Komor, E.; M. Rotter; J. Waldhauser; E. Martin, and B. H. Cho, (1980). Sucrase proton symport for phloem loading in the ricinus seedlings. Ber. Deutsh. Bot. Ges., 93: 211-219.

Merlo, L.; R. Ghisi; N. Rascio and C. Passera (1991). Effects of humic substances on carbohydrate metabolism of maize leaves. Canadian $\mathrm{J}$. Plant Sci., 71: 419-425.

Meshref, H. A.; M. H. Rabie; A. M. El-Ghamry and M. A. El-Agamy (2010). Maximizing utilization of compost addition using foliar compost extracts and humic substances in alluvial soils. J. Soil Sci. and Agric. Engineering, Mansoura Univ., 1(9):957-971 .

Mikkelsen, R. L. (2005). Humic materials for agriculture. Better Crops, 89(3):6-10.

Murquard, R. D. and J. L. Timpton (1987). Relationship between extractable chlorophyll and an insitu method to estimate leaf green. Hort. Sci., 22(6): 1327.

Nahar, K. and R. Gretzmacher (2002). Effect of water stress on nutrient uptake, yield and quality of tomato (Lycopersicon esculentum Mill.) under subtropical conditions. Die Bodenkultur, 53 (1): 45- 51.

Nardi, S.; D. Pizzeghello; A. Muscolo and A. Vianello (2002). Physiological effects of humic substances on higher plants. Soil Biology and Biochem., 34:1527-1536.

Olsen, S. R. and L. E. Sommers (1982). Phosphorus. In: Page, A. L.; R. H. Miller and D. R. Keeney (eds). Methods of soil analysis. Part 2 Amer. Soc. Agron. Madison, W. I. USA, pp. 403-430.

Osman, A. S. and A. A. A. Abdel All (2008). The possible use of humic acid incorporated with drip irrigation system to alleviate the harmful effects of saline water on tomato plants. Fayoum J. Agric. Res. and Dev., 22(1):52-70.

Page, A. L. (1982). Methods of Soil Analysis. $2^{\text {nd }}$ ed., Part 1, Soil Sci. Soc. Amer., Madison, Wisc., USA.

Pinton, R.; S. Cesco; S. Santi; F. Agnolon and Z. Varanini (1999). Waterextractable humic acids enhance iron deficiency responses by $\mathrm{Fe}$ deficient cucumber plants. Plant Soil, 210: 145-157.

Polat, E.; M. Karaca; H. Demir and A. O. Nacio (2004). Use of natural zeolite (Clinoptilolite) in agriculture. J. Fruit Ornam. Plant Res., 12:183-189.

Senedcor, G. W. and W. G. Cochran (1980). Statistical Methods. $7^{\text {th }}$ ed lowa State Univ., Press, Ames, USA.

Selim, E. M; A. S. El-Neklawy and A. A. Mosa (2010). Humic acid fertigation of drip irrigated cowpea under sandy soil conditions. AmericanEurasian J. Agric. and Environ. Sci., 8(5):538-543. 
Shinohara, Y.; K. Akiba, T. Maruo and T. Ito (1995). Effect of water stress on the fruit yield, quality and physiological condition of tomato plants using the gravel culture. Acta Hort., 396:211-218.

Taiz, L. and E. Zeiger (2002). Plant physiology, $3^{\text {rd }}$ edn., Sinauer Associates, Sunderland, Mass.

Turner, N. C. (1981). Techniques and experimental approaches for the measurement of plant water stress. Plant Soil, 58:339-366.

Valente, S.; N. Burriesci, S. Cavallaro; S. Galvagno and C. Zipelli (1986). Utilization of zeolite as soil conditioner in tomato growing. Zeolites, 2:271-274.

Waller, R. A. and D. B. Duncan (1969). A bayes for the symmetric multiple comparison problem. J. Amer. Stat. Assoc., 64:1484-1503.

Zhai, Y. M.; X. H. Shao; W. G. Xing; Y. Wang; T. T. Hung and H. L. Xu (2010). Effects of drip irrigation regimes on tomato fruit yield and water use efficiency. J. Food, Agric. and Enviro., 8(3 and 4):709-713.

Zhang, X. and E. H. Ervin (2004). Cytokinin containing seaweed and humic acid extracts associated with creeping bentgrass leaf cytokinins and drought resistance. Crop Sci., 44:1737-1745.

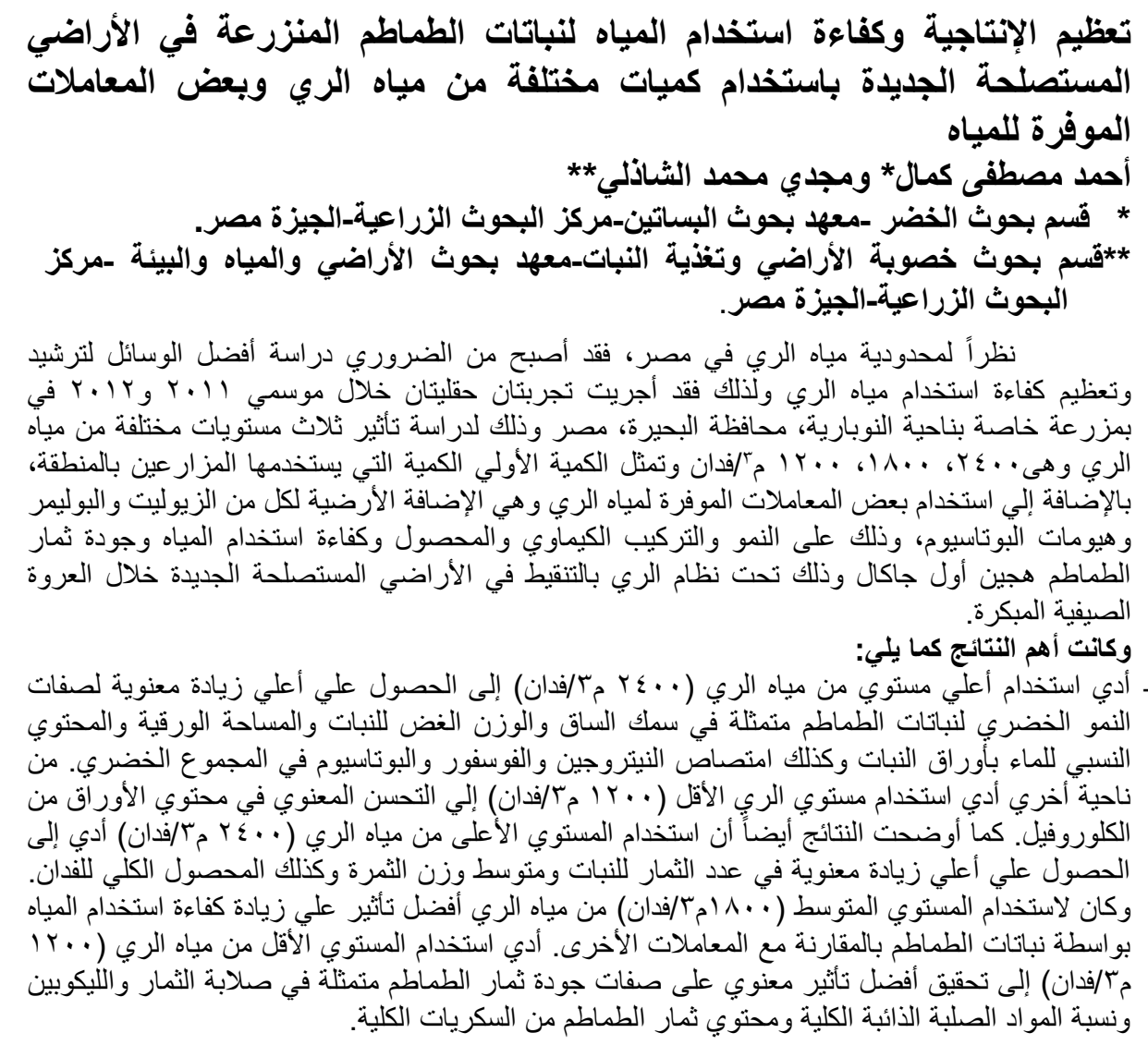




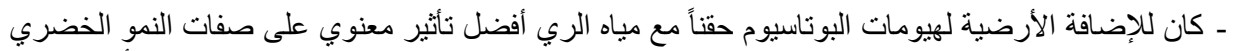

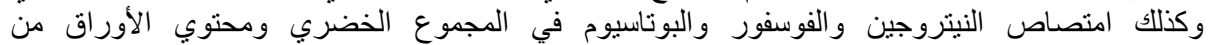

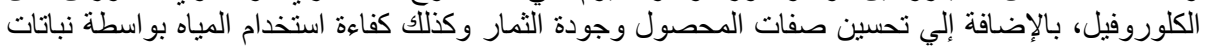

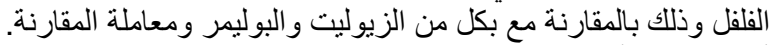

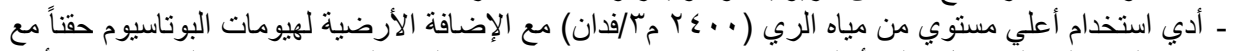

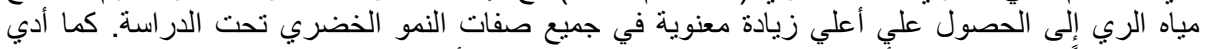

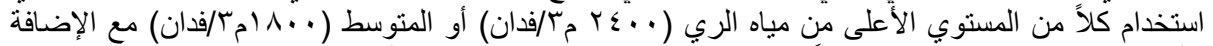

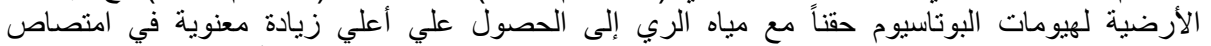

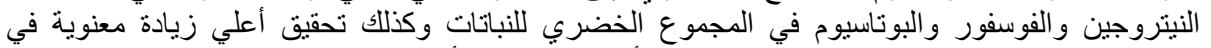

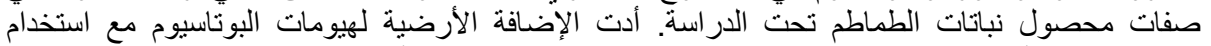

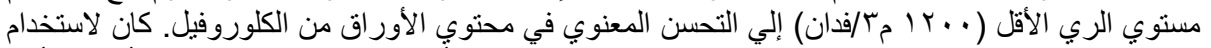

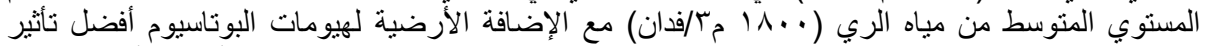

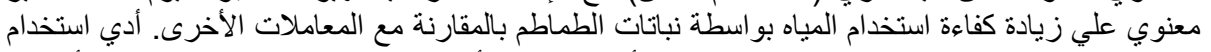

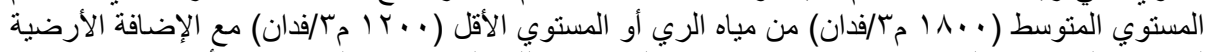

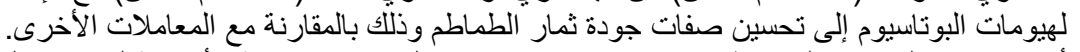

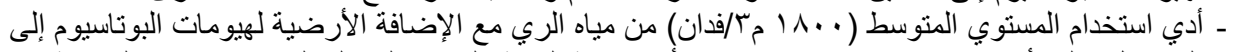

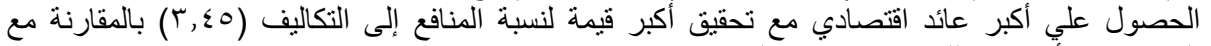

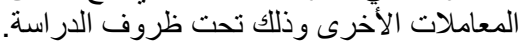

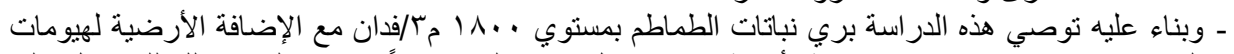

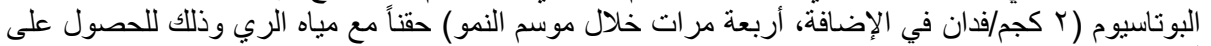

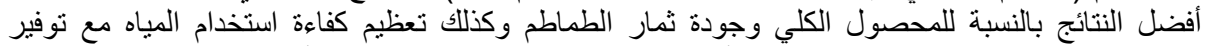

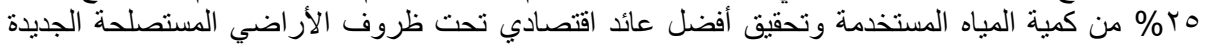
في العروة الصيفية المبكرة.

كلية الزراعة - جامعة المنصورة مركز البحوث الزراعيه

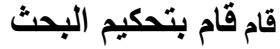

أ.ـد / السيد احمد طرطوره أ.د / عبد الحميد حبشى عامر احر 